\title{
Urgences
}

\section{t'écrire qu'au matin...}

\section{Sonia Talbot}

Numéro 15, octobre 1986

Épigraphiques

URI : https://id.erudit.org/iderudit/025350ar

DOI : https://doi.org/10.7202/025350ar

Aller au sommaire du numéro

Éditeur(s)

Urgences

\section{ISSN}

0226-9554 (imprimé)

1927-3924 (numérique)

Découvrir la revue

Citer ce document

Talbot, S. (1986). t'écrire qu'au matin... Urgences, (15), 92-92.

https://doi.org/10.7202/025350ar

Ce document est protégé par la loi sur le droit d'auteur. L’utilisation des services d'Érudit (y compris la reproduction) est assujettie à sa politique d'utilisation que vous pouvez consulter en ligne.

https://apropos.erudit.org/fr/usagers/politique-dutilisation/
Cet article est diffusé et préservé par Érudit.

Érudit est un consortium interuniversitaire sans but lucratif composé de l’Université de Montréal, l'Université Laval et l'Université du Québec à Montréal. Il a pour mission la promotion et la valorisation de la recherche. https://www.erudit.org/fr/ 


\section{Sonia Talbot}

O CETTE FUITE DIT-ELLE CETTE DOULEUR INSUPPORTABLE...

Françoise Thieck, dans Gérard Mauri: $O b$ jectives $18 \mathrm{~mm}$.

t'écrire qu'au matin tu prenais ta première avec moi avec moi? avec le journal les déjà vieilles nouvelles du jour qui ne faisait que débiter en siruper quelques lampées thérapeutiques histoire de poursuivre l'existence qui ne prenait vie qu'à la promenade avec les gens qui s' offusquaient à la vue de la chienne errante en corps leur dire: "LE MAITRE OSSEUX N'A PAS D'MÉDAILLE."

écrire aussi pour décrire ce rituel en fumée lui: souvent répété, elle: souvent embrassée, moi: sous noroît jalouse cette préférée que tu désirais air conditionné, enlaçais doigts tremblants, léchais langue sèche, enflammais feu ardent désirant partager ce plaisir ton plaisir j'me brûlais merde

et rire ensuite quand tu entamais ta cinquième grosse bière mon minou moi et ma moindre seconde grosse bière right through donnait le tempsà traverser dépassais ta sale consommation d'alcool non la mienne me rappeler que tu n'auras plus à me souhaiter malgré tout une bonne nuit pour mieux...

HORRESCO REFERENS 